\title{
Potential application of natural phenolic antimicrobials and edible film technology against bacterial plant pathogens
}

\author{
Derya Alkan, Ahmet Yemenicioğlu* \\ Department of Food Engineering, Faculty of Engineering, Izmir Institute of Technology, 35430, Gülbahçe Köyü, Urla, Izmir, Turkey
}

\section{A R T I C L E I N F O}

\section{Article history:}

Received 8 May 2015

Received in revised form

1 August 2015

Accepted 29 October 2015

Available online 10 November 2015

\section{Keywords:}

Phenolic acid

Essential oil

Phenolic extracts

Plant pathogen

Antimicrobial film

Zein

\begin{abstract}
A B S T R A C T
The aim of the present study is to use antimicrobial edible film technology and natural phenolic antimicrobials for inhibition of major bacterial plant pathogens such as Erwinia amylovora, Erwinia carotovora, Xanthomonas vesicatoria and Pseudomonas syringae. For this purpose phenolic acids (PAs) (gallic (GA), vanillic (VA), cinnamic acids (CA)), essential oils (EOs) (carvacrol (CAR), thymol (THY), eugenol (EUG) citral (CIT)), phenolic extracts (PEs) from clove (CE), oregano (OE), artichoke stem (ASE) and walnut shells (WSE) were evaluated as antimicrobial zein film components. Films containing PAs between 1 and $4 \mathrm{mg} / \mathrm{cm}^{2}$ inhibited all pathogens while EOs between 1 and $4 \mathrm{mg} / \mathrm{cm}^{2}$ and CE between 4 and $8 \mathrm{mg} / \mathrm{cm}^{2}$ inhibited pathogens except $P$. syringae. The most potent films were obtained by using GA against $E$. amylovora and $P$. syringae, VA against E. carotovora, and CA, THY or CAR against X. vesicatoria. The addition of phenolic compounds into films increased the porosity of films. The phenolic containing films also become more flexible and lost their brittleness. This study is important in that it prepared the basis of using edible antimicrobial coatings in outdoor applications on infected tree stems, soil surfaces and agronomy tools or in classical fruit and seedling coating applications to control bacterial contamination or spoilage.
\end{abstract}

(C) 2015 Elsevier Ltd. All rights reserved.

\section{Introduction}

The use of edible biopolymeric materials and natural antimicrobial compounds in antimicrobial packaging provides a promising alternative method to inhibit the growth of pathogenic and spoilage microorganisms in food and to increase safety and quality of food products. Thus, extensive studies have been conducted in the recent years to develop edible films and coatings from biopolymers such as zein, whey proteins, soy proteins, chitosan, alginate, carrageenan, pullulan, cellulose and its derivatives (Gniewosz et al., 2014; Joerger, 2007; Mendes de Souza, Fernández, LópezCarballo, Gavara, \& Hernández-Muñoz, 2010; Rojas-Grau et al., 2007; Zhong, Cavender, \& Zhao, 2014). Different natural antimicrobials including phenolic extracts, essential oils, bacteriocins and antimicrobial enzymes have been incorporated into edible films to obtain antimicrobial packaging materials (Alboofetileh, Rezaei, Hosseini, \& Abdollahi, 2014; Appendini \& Hotchkiss, 2002; Atares, Bonilla, \& Chiralt, 2010; Benavides, Villalobos-Carvajal, \&

\footnotetext{
* Corresponding author.

E-mail address: ahmetyemenicioglu@iyte.edu.tr (A. Yemenicioğlu)
}

Reyes, 2012; Del Nobile, Conte, Incoronato, \& Panza, 2008; GómezEstaca, López de Lacey, López-Caballero, Gómez-Guillén, \& Montero, 2010; Li, Yin, Ynag, Tang, \& Wei, 2012; Mastromatteo, Mastromatteo, Conte, \& Del Nobile, 2010; Salgado, López-Caballero, Gómez-Guillén, Mauri, \& Montero, 2012).

The antimicrobial packaging targets mainly the inhibition of human pathogenic bacteria such as Listeria monocytogenes, Staphylococcus aureus, Escherichia coli 0157:H7, Pseudomonas fluorescence and Salmonella sp. in food (Du et al., 2009; Han, 2005; Kanmani \& Rhim, 2014; Shakeri, Shahidi, Beiraghi-Toosi, \& Bahrami, 2011; Ünalan, Arcan, Korel, \& Yemenicioğlu, 2013). The antimicrobial packaging could also target food spoilage yeasts and molds and non-pathogenic spoilage bacteria such as Bacillus spp. and Lactobacillus spp. (Kraśniewska et al., 2014; Manso, CachoNerin, Becerril, \& Nerìn, 2013; Mecitoglu et al., 2006). However, there are no studies in the literature to employ antimicrobial edible coating technology for the inhibition of bacterial plant pathogens. The percent crop spoiled by the plant pathogens change between $10 \%$ and $16 \%$ of the total crop grown in the world (Chakrabarty \& Newton, 2011). Thus, severe use of toxic chemicals to prevent economic losses in orchards and fields is a widespread problem (Pimentel, 2002). As a novel approach the edible antimicrobial 
coatings containing natural active compounds could be applied in the orchards for coating of contaminated tree stems, and in the fields on plants, soil surfaces or agronomy tools and equipment to suppress infections caused by bacterial plant pathogens without using toxic chemicals. Such an application could help suppression of diseases like Bacterial canker mediated by some pathovars of Pseudomonas syringae and causes important damages in the stems and leaves of Prunus (plums, cherries, apricots and peaches) trees. Different authorities including the Royal Horticultural Society advises the application of copper-based chemicals like Bordeaux mixture (originally a fungicide) on three stems to control Bacterial canker (https:/www.rhs.org.uk.). However, the Bordeaux mixture obtained by mixing copper-sulfate with lime is a hepatotoxin persistent in the soil and it leads to documented health problems in farm workers (Bolan et al., 2014; Dixon, 2004; Mackie, Müller, \& Kandeler, 2012).

Although the application of edible coatings in orchards and fields is a novel approach, the application of edible films for coating of fresh fruits and vegetables is a well-known practical process used to reduce their respiration rates and senescence (Park, 1999). For a successful fruit and vegetable coating application, the gas permeability characteristics of the coating material and the product respiration rate should be compatible. This helps to obtain the "modified atmosphere effect" that forms by reduction of fruit or vegetable respiration rate under reduced $\mathrm{O}_{2}$ and elevated $\mathrm{CO}_{2}$ atmospheres and to extend the shelf life of the coated product (Park, 1999; Rojas-Graü, Oms-Oliu, Soliva-Fortuny, \& Martín-Belloso, 2009). The biopolymers like cellulose, casein, zein, soy proteins and chitosan are frequently applied for fruit coating due to their desired gas permeability characteristics and other characteristics such as being odorless, tasteless and transparent (Lin \& Zhao, 2007; RojasGraü et al., 2009). The application of zein as a fruit coating material attracts a particular interest since zein is the major co-product of the oil industry and rapidly growing bio-ethanol industry. The zein is also one of the rare hydrophobic proteins and it gives excellent coatings with good gas and moisture barrier properties (Lin \& Zhao, 2007). Moreover, the zein films provide an effective delivery system for different natural active compounds including phenolic compounds (Arcan \& Yemenicioğlu, 2011, 2014). Thus, the zein coatings have been successfully applied on different fruits including apples (Bai, Baldwin, \& Hagenmaier, 2002), pears (Scramin et al., 2011), mangoes (Gol \& Rao, 2014) and tomatoes (Zapata et al., 2008) to delay their ripening process and to reduce their moisture loss during storage. However, no studies have been conducted to design antimicrobial edible zein fruit coatings specifically against bacterial plant pathogens so far. The natural antimicrobial coatings could also be applied to control postharvest spoilage of root vegetables like cold stored potatoes spoiled largely by specific bacterial plant pathogens (Mills, Platt, \& Hurta, 2006; Wood, Miles, \& Wharton, 2013). Such an antimicrobial coating application could also be beneficial for tubers separated as seedling and it might reduce the disease problems in the field without using classical chlorine based potentially toxic and odorous chemicals. Thus, the aim of the present study is to adopt the principles of antimicrobial edible packaging for inhibition of major bacterial plant pathogens such as Erwinia amylovora, Erwinia carotovora, Xanthomonas vesicatoria and $P$. syringae which cause different plant diseases and great economic losses in fruits and vegetables at preharvest and postharvest stages (Hao \& Brackett, 1994; Mills et al., 2006). For this purpose, edible zein films were incorporated with different antimicrobial phenolic acids, and phenolic rich essential oils and plant extracts. The use of natural phenolic agents in edible films has become increasingly popular since these compounds are not only potent antimicrobials, but they also have different bioactive effects on human including antioxidant, anticancerogenic, antidiabetic and antihypertensive activities (Basgedik, Aysel, \& Nurdan, 2014; Moure et al., 2001; Wojdyło, Teleszko, \& Oszmiański, 2014). In the literature, the effects of different phenolic rich essential oils on fungal plant pathogens and development of antifungal edible fruit coatings for postharvest decay control have been studied (Sivakumar \& Bautiata-Banos, 2014). However, there are only few studies related to antimicrobial potential of phenolic compounds on bacterial plant pathogens. For example, the inhibitory effects of phenolic compounds towards growth of Xylella fastidiosa, a plant pathogen that causes diseases in different crop species, has been reported by Maddox, Laur, and Tian (2010). Luzzatto et al. (2007) found that the use of different plant defense activators with phenolic compounds contributes to increased resistance against soft-rot pathogen Pectobacterium carotovorum. Mohana and Raveesha (2006) reported the antimicrobial effects of Caesalpinia coriaria (Jacq.) Willd extracts on Xanthomonas pathovars. However, the present study was the first one in the literature which investigated the potential application of natural phenolic antimicrobials and edible film technology against major bacterial plant pathogens. This work made a contribution to increase use of antimicrobial edible coatings not only for fruit coating, but also for coating of soil surfaces and agronomic tools, tree stems, and seedlings.

\section{Materials and methods}

\subsection{Materials}

Zein, GA, CA, VA, CAR, THY, EUG, and CIT used in film making were obtained from Sigma Chem Co. (St. Louis, MO). Glycerol and ethanol were purchased from Merck (Darmstadt, Germany). Nutrient broth and buffered peptone water were obtained from Oxoid Ltd. (Hampshire, United Kingdom). Nutrient agar used in antimicrobial tests was obtained by adding 1.4\% agar (Applichem, Darmstadt, Germany) in nutrient broth prepared according to the user's manual. All the other chemicals were reagent grade.

\subsection{Bacterial cultures}

The four plant pathogenic bacteria; E. carotovora (RK-EC-462), $X$. vesicatoria (RK-XCV-110C), E. amylovora (RK-EA-228) and P. syringae (P.syr-RK-453) were kindly provided by Assoc. Prof. Recep Kotan from the Faculty of Agriculture at Atatürk University, Turkey.

\subsection{Preparation of plant extracts}

The extraction of phenols from plant materials was carried out according to Chun, Vattem, Lin, and Shetty (2005) with slight modification. Plant materials (1-5 g) (dry mortar crushed oregano, clove and walnut shells and chopped fresh artichoke stems) were placed into a beaker containing $100 \mathrm{~mL}$ of ethanol (60\%) and the extraction was carried out at room temperature under continuous magnetic stirring for $24 \mathrm{~h}$. The mixture was then centrifuged at $9000 \mathrm{rpm}$ for $14 \mathrm{~min}$. After that the supernatant was collected and concentrated in a rotary evaporator working under vacuum at 100 mbar and $40^{\circ} \mathrm{C}$. The concentrated extract was then lyophilized to obtain dry PE powder. The PEs suitable for film making were selected depending on their minimum inhibitory concentration (MIC) on plant pathogens.

\subsection{Antimicrobial activity of plant extracts}

The MICs of PE were determined in broth medium using 96-well microplates. A stock solution of each PE was prepared in nutrient broth at a concentration of $41 \mathrm{mg} / \mathrm{mL}$ and then series of two-fold 
dilutions of these solutions were prepared until obtaining the lowest concentration of $0.01 \mathrm{mg} / \mathrm{mL}$. The inoculums of microorganisms were prepared using $48 \mathrm{~h}$ cultures, and suspensions were adjusted to 2 McFarland standard turbidity. The wells of 96-well plate were filled with $10 \mu \mathrm{L}$ of inoculants, $90 \mu \mathrm{L}$ of nutrient broth, and $100 \mu \mathrm{L}$ of various concentrations of PEs. Three wells were prepared for each concentration of PEs. A positive control (containing inoculums, but not PEs) and negative controls (containing PEs, but not inoculums) were included on each microplate. Plates were incubated at $27^{\circ} \mathrm{C}$ for $24 \mathrm{~h}$ under aerobic conditions and their absorbencies were recorded at $600 \mathrm{~nm}$ in every $15 \mathrm{~min}$ to detect microbial growth. The controls and cultures containing plant extracts were tested in triplicate wells at each studied concentrations, and averages of absorbance values versus time (minutes) were plotted to obtain growth curves. The degree of inhibition was calculated using the formula: $\%$ inhibition $=100-[(S 1 / S 2) \times 100]$, where $S 1$ is the slope of the best-fitting curve for a culture with plant extracts and S2 is the slope of the best-fitting curve for the control (culture) at the linear growth phase of absorbance-time curves.

\subsection{Phenolic content of plant extracts}

The total phenolic content of plant extracts was determined by using the Folin-Ciocalteu reagent as described in Singleton and Rossi (1965). The reaction mixture contained $100 \mu \mathrm{L}$ of plant extracts, $1 \mathrm{~mL}$ of the Folin-Ciocalteu reagent and $0.8 \mathrm{~mL}$ of sodium carbonate $(20 \% \mathrm{w} / \mathrm{v})$. The final volume was made up to $2 \mathrm{~mL}$ with distilled water. After $2 \mathrm{~h}$ of reaction, the absorbance at $765 \mathrm{~nm}$ was measured. The calibration curve was formed by using GA as standard. Phenolic content was expressed as milligrams of GA equivalents (GAE) per gram of the extract powder. The amount of GA, the major active nonvolatile phenolic compound in the clove extracts, was determined by an HPLC analysis using an HPLC System (Perkin Elmer series 200 Shelton, CT USA), equipped with a binary pump and a diode-array detector (DAD) and a Nucleosil 100-C18 column $(5 \mu \mathrm{m}, 250 \times 4 \mathrm{~mm})$. Phenolic compounds in the CE were analyzed using the HPLC method described by Shan, Cai, Sun, and Corke (2005). The HPLC method was carried out with the following gradient elution program (solution A, $2.5 \%$ formic acid, and solution B, 100\% methanol): 0 min, 5\% B; 15 min, 30\% B; 40 min, 40\% B; $60 \mathrm{~min}, 50 \% \mathrm{~B}$; $65 \mathrm{~min}, 55 \% \mathrm{~B}$; and $90-95 \mathrm{~min}, 100 \% \mathrm{~B}$. The flow rate was $0.8 \mathrm{~mL} / \mathrm{min}$, and the injection volume was $20 \mu \mathrm{L}$. The phenolic compounds were detected at $280 \mathrm{~nm}$. Individual peaks identified in CE were analyzed by comparison with that of the external standard of GA used to form the calibration curve. Results were reported as $\mathrm{mg} \mathrm{GA} / \mathrm{g}$ of extract powder.

\subsection{Film making}

Zein films were produced as described in Padgett, Han, and Dawson (1998). Briefly, $1.4 \mathrm{~g}$ corn zein was dissolved with $8.2 \mathrm{~mL}$ of ethanol (97\%) by mixing at $200 \mathrm{rpm}$ with a magnetic stirrer for $25 \mathrm{~min}$. Then, $0.4 \mathrm{~mL}$ glycerol was added into the mixture, and the temperature of the mixture was increased until it started to boil. The mixing was then ceased and the film solution was boiled for $5 \mathrm{~min}$. After cooling to room temperature different phenolic acids, essential oils or plant extracts were added into film forming solutions (0.03-0.9 $\mathrm{g}$ per $\mathrm{g}$ of film forming solution). The final concentrations of active compounds in the films obtained by this procedure changed between 0.25 and $8 \mathrm{mg}$ per $\mathrm{cm}^{2}$ of dried films. The mixtures were then homogenized (Heidolph, Germany, rotor $\Phi=6.6 \mathrm{~mm}$ tip) at $10,000 \mathrm{rpm}$ for $4 \mathrm{~min}$ and $4.3 \mathrm{~g}$ portions of homogenates were poured into glass templates $(\mathrm{W} \times \mathrm{L} \times \mathrm{H}$ : $8.5 \times 8.5 \times 0.4 \mathrm{~cm})$. All films were dried at $25{ }^{\circ} \mathrm{C}$ for $19 \mathrm{~h}$ in an incubator. However, for only films used in mechanical testing an additional conditioning was applied to films at $25^{\circ} \mathrm{C}$ for $24 \mathrm{~h}$ under $50 \%$ relative humidity using a controlled test cabinet (TK 120, Nüve, Turkey). The dried films peeled from the glass templates carefully were used in different tests.

\subsection{Antimicrobial activity of films}

Fifteen discs ( $1.3 \mathrm{~cm}$ in diameter) were prepared from films by a cork borer under aseptic conditions. During tests, 3 discs were placed carefully onto each Petri dish containing nutrient agar previously inoculated with different plant pathogens. The inoculums of microorganisms were prepared in peptone water using a $48 \mathrm{~h}$ culture of plant pathogens incubated at aerobic conditions at $27^{\circ} \mathrm{C}$. Before tests, the cell concentration was set to $0.5 \mathrm{McF}$ arland (corresponded to $150 \times 10^{6} \mathrm{cfu} / \mathrm{mL}$ ) and Petri dishes were inoculated by spread plate method by using $0.2 \mathrm{~mL}$ of culture diluted 1:10 with peptone water. The inoculated Petri dishes containing film discs were incubated at aerobic conditions at $27^{\circ} \mathrm{C}$ for $24 \mathrm{~h}$ and the diameter of the zones formed was measured by using a caliper. Results were expressed as average zone areas $\left(\mathrm{mm}^{2}\right)$.

\subsection{Mechanical properties of films}

Tensile strength at break, elongation at break, and Young's modulus were determined using a Texture Analyzer TA-XT2 (Stable Microsystems, Godalming, United Kingdom) according to ASTM Standard Method D 882-02 (ASTM, 2002). Films were cut into $8 \mathrm{~mm}$ wide and $80 \mathrm{~mm}$ length strips. The initial grip distance was $50 \mathrm{~mm}$, and the crosshead speed was $25 \mathrm{~mm} / \mathrm{min}$. Five replicates of each film were tested.

\subsection{Scanning electron microscopy (SEM) of films}

The photographs of film cross-sections and film thickness were determined by SEM (Philips XL 30S FEG, FEI Company, Netherlands). The films were prepared for SEM by crashing, following freezing in liquid nitrogen. The thickness of the films was measured from SEM cross-sectional views of films by using Scandium software (Olympus Soft Imaging Solutions).

\subsection{Statistical analysis}

Data including measurements obtained from mechanical properties of films were analyzed by analysis of variance (ANOVA). Fisher's protected least significant difference method was used for comparison of means. Differences were considered significant if $P<0.05$.

\section{Results and discussion}

\subsection{Antimicrobial activity of PA containing films}

The photographs of selected inhibition zones are displayed in Fig. 1 while overall results of antimicrobial activities of GA, VA, and CA incorporated zein films on different plant pathogens are displayed in Fig. 2A to D. The films containing PAs between 1 and $4 \mathrm{mg} / \mathrm{cm}^{2}$ showed antibacterial effect on all of the four plant pathogens. The most potent and dose dependent antimicrobial films were obtained by using GA against E. amylovora and $P$. syringae, and VA against $E$. caratovora, and $X$. vesicatoria. The CA containing films were also highly effective against $X$. vesicatoria, but the concentration of PA in films could not be increased above $2 \mathrm{mg} /$ $\mathrm{cm}^{2}$ since films produced at higher concentrations of CA could not be peeled from the cast surfaces. The GA was the only phenolic acid 


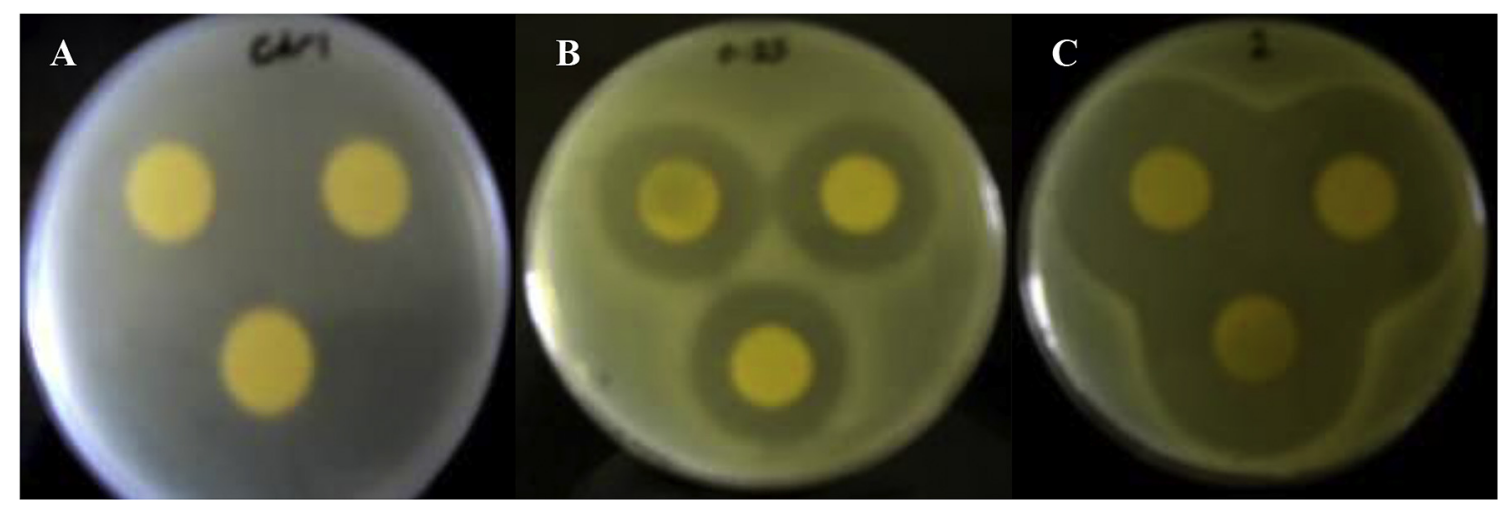

Fig. 1. Photographs of inhibition zones formed by GA containing films on E. amylovora (A: Controls, B: $0.25 \mathrm{mg} / \mathrm{cm}^{2} \mathrm{GA}$ containing films, C: $2.0 \mathrm{mg} / \mathrm{cm}^{2} \mathrm{GA}$ containing films).

having a considerable dose dependent antimicrobial effect on all plant pathogens. However, E. amylovora and P. syringae were particularly susceptible to the action of GA and inactivated much more effectively than $E$. carotovora and $X$. vesicatoria by this phenolic acid. In the literature, the potent antimicrobial activity of GA and its derivatives have been reported in several studies (Fogliani, Raharivelomanana, Bianchini, Bouraima-Madjebi, \& Hnawia, 2005; Shukla, Srivastava, Kumar, \& Kumar, 1999). The mechanism of action for GA was also investigated for E. coli, Pseudomonas aeruginosa, S. aureus, and L. monocytogenes and it was attributed to physicochemical changes in integrity and permeability of bacterial membranes caused by GA (Borges, Ferreira, Saavedra, \& Simões, 2013). The GA has one carboxylic acid and three hydroxyl groups and its bioactive properties including antioxidant and antimicrobial activity originate from number and positions of these functional groups (Fig. 3). The VA, the second most effective PA after GA, contains one carboxyl and one hydroxyl groups while CA, the least effective $P A$, contains only a single carboxyl group. Thus, it is clear that the number of hydroxyl group for the PAs is a quite critical factor for their antimicrobial potential.

\subsection{Antimicrobial activity of EO containing films}

The films containing EOs between 1 and $4 \mathrm{mg} / \mathrm{cm}^{2}$ inhibited all plant pathogens except $P$. syringae which is the most resistant bacteria against EOs (Fig. 2E to $\mathrm{H}$ ). The EUG was the only EO effective on $P$. syringae, but its antimicrobial activity was very low and it was observed only at the highest concentration $\left(4 \mathrm{mg} / \mathrm{cm}^{2}\right)$. The most potent films were obtained by using $4 \mathrm{mg} / \mathrm{cm}^{2}$ concentrations of THY, CAR and CIT against $X$. vesicatoria, CIT against E. amylovora and THY and CIT against E. carotovora. It is worth to note that the films containing THY, CAR or CIT at $4 \mathrm{mg} / \mathrm{cm}^{2}$ concentration caused effective inactivation of the indicated inoculated bacteria and prevented their growth in the Petri dishes completely. These results showed that the CIT, potent on three of the bacteria, is the most effective EO on plant pathogens. The THY, potent on two of the bacteria, and CAR, potent on one of the bacteria, are the second and third effective EOs on plant pathogens, respectively. In contrast, the EUG is the least effective EO and did not show potent antimicrobial activity against any of the plant pathogens. The careful analysis of the formulas for EUG, THY and CAR suggested that the lacking branched methylene groups could be the factor limiting the potency of EUG. On the other hand, the CIT might owe its potency to its different conformation than the other EOs. The CIT is an acyclic monoterpene aldehyde (Fig. 3) and it might face less steric hindrance and barrier effect from pores at the bacterial membranes. The most sensitive bacteria against EOs is $X$. vesicatoria which was completely inhibited on the Petri dishes with films containing three of the EOs (THY, CAR and CIT) at $4 \mathrm{mg} / \mathrm{cm}^{2}$ concentration. It was also only $X$. vesicatoria which showed considerable inhibition by films containing EOs (CAR, THY) at $2 \mathrm{mg} / \mathrm{cm}^{2}$. The analysis of the inhibition curves for EOs clearly showed the relationships between zone area and EO concentrations. The inhibition of all plant pathogens by EOs was concentration dependent manner. However, the relationship between zone area and EO concentration for a given bacteria turned linear to logarithmical as EO concentration was increased. The inactivation of bacteria by phenolic compounds may occur by multiple mechanisms including complex formation with cell walls, membrane disruption, inhibition of bacterial adhesion or inactivation of bacterial enzyme systems (Cowan, 1999). Thus, it seemed that the number of mechanism effective on inhibition increased by the increased concentrations of EOs which contain mixture of different phenolic compounds.

\subsection{Antimicrobial activity of PES}

Different PEs, OE, ASE, WSE and CE, containing $176.0 \pm 9.3$, $35.4 \pm 2.1,110.2 \pm 5.2,274.1 \pm 36.5 \mathrm{mg} \mathrm{GAE} / \mathrm{g}$, respectively, were first tested directly against plant pathogens to evaluate their potential application as antimicrobial film component. The antimicrobial tests were conducted in broth growth medium to determine the MICs of different PEs between 0.01 and $41 \mathrm{mg} / \mathrm{mL}$ concentration range and to select the most potent PE for film making. The results of the present study clearly showed that the $\mathrm{CE}$ was the most potent PE and it was effective on all plant pathogens. The MIC determined for CE was $10.24 \mathrm{mg} / \mathrm{mL}$ for all of the four plant pathogens. In the presence of $\mathrm{CE}$ at concentrations below MIC, for example at $5.12 \mathrm{mg} / \mathrm{mL}$, E. carotovora, $X$. vesicatoria and E. amylovora showed $44 \%, 77 \%$ and $82 \%$ inhibitions, respectively. In contrast, $P$. syringae did not show any inhibition at the CE concentration of $5.12 \mathrm{mg} / \mathrm{mL}$ (Table 1). In presence of CE at $2.56 \mathrm{mg} / \mathrm{mL}$, E. carotovora and $P$. syringae did not show any inhibition while E. amylovora and $X$. vesicatoria showed $42 \%$ and $57 \%$ inhibition, respectively. The PEs other than CE did not cause complete inhibition in growth of the bacteria at broth medium between 0.01 and $41 \mathrm{mg} / \mathrm{mL}$ concentration range. However, the $\mathrm{OE}$ at $41 \mathrm{mg} / \mathrm{mL}$ showed $47 \%, 90 \%$ and $91 \%$ inhibition against $E$. carotovora, $X$. vesicatoria and $E$. amylovora, respectively. Moreover, ASE at $41 \mathrm{mg} / \mathrm{mL}$ showed $48 \%, 48 \%$ and $68 \%$ inhibition against E. carotovora, E. amylovora and $X$. vesicatoria, respectively. However, both ASE and OE did not show any inhibition on $P$. syringae in broth medium at the studied concentration range. These results suggested that the most resistant bacterium against PEs was $P$. syringae. The E. caratovora was the second most resistant bacteria against tested PEs while $E$. amylovora and $X$. vesicatoria 

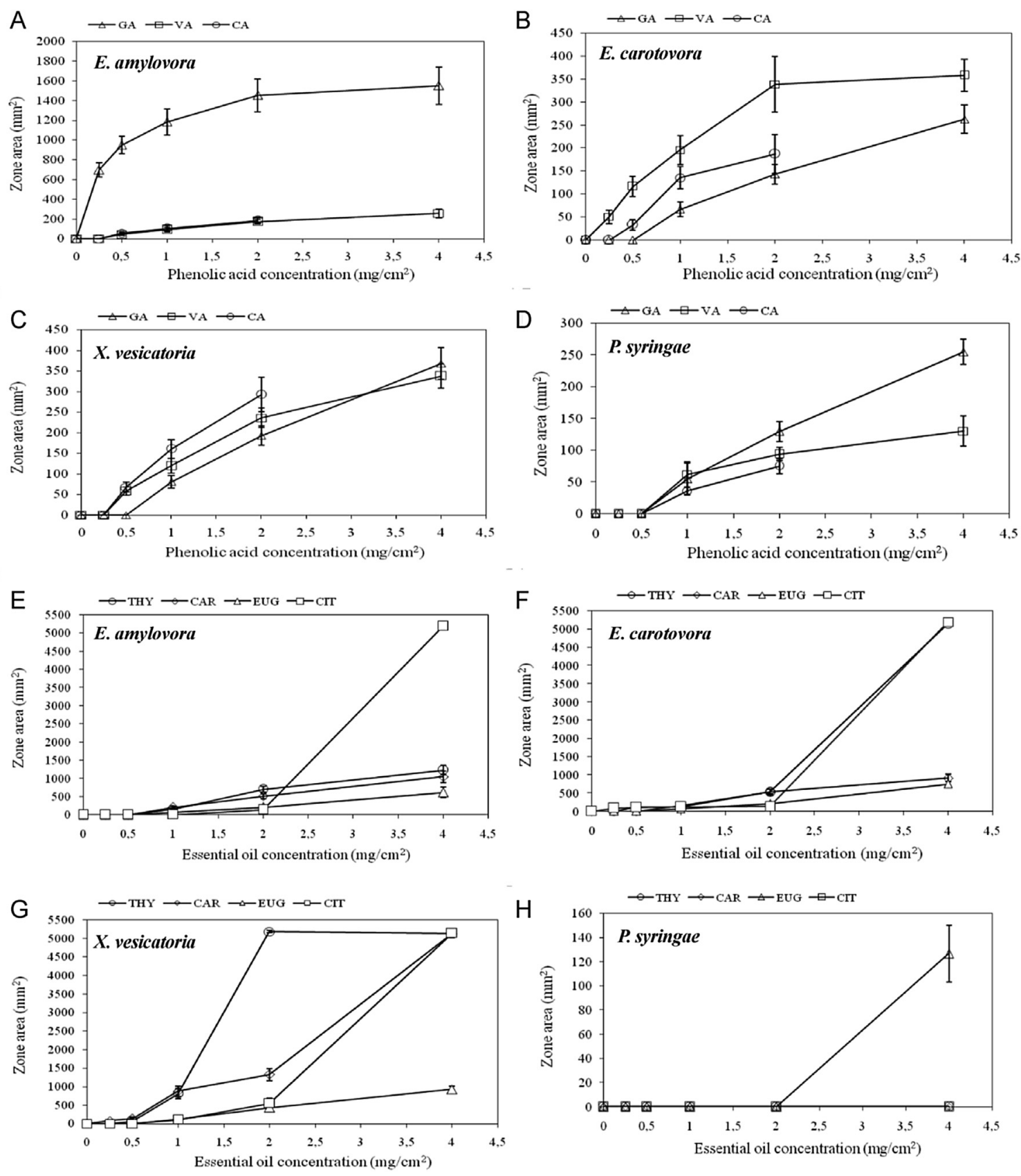

Fig. 2. Antimicrobial activities of phenolic acid and essential oil containing zein films on different plant pathogens.

showed highest susceptibilities against PEs at the test conditions.

\subsection{Antimicrobial activity of PE containing films}

The CE was selected as the most suitable PE for film making since it showed antimicrobial activity on all plant pathogens grown in broth medium. The CE is a crude phenolic extract with a total phenolic content of $274 \mathrm{mg}$ GAE/g. Thus, the CE concentration in the films should be minimum at $4 \mathrm{mg} / \mathrm{cm}^{2}$ to obtain antimicrobial films against $E$. amylovora and $X$. vesicatoria while the inhibition of more resistant $E$. caratovora needs incorporation of CE into films minimum at $6 \mathrm{mg} / \mathrm{cm}^{2}$ (Fig. 4). In contrast, no antimicrobial effect was observed on $P$. syringae even when the CE concentration in the films was increased as high as $8 \mathrm{mg} / \mathrm{cm}^{2}$. This result was expected since resistance of $P$. syringae on CE was also observed during MIC determination in the broth medium. Shan et al. (2005) determined that the GA and its derivatives and volatile phenolic oils like eugenol and acetyl eugenol are the main phenolic components of clove methanolic extracts. These workers determined GA as the major nonvolatile phenolic compound in the clove and reported presence of $7.8 \mathrm{mg}$ GA per $\mathrm{g}$ (d.w.) of this spice. The CE is free from volatile phenolic oils, since it was extensively dried in powder by lyophilization following concentration with rotary evaporator. However, the HPLC analysis of CE clearly showed the presence of $22 \mathrm{mg}$ GA per $\mathrm{g}$ of CE. Thus, the amount of GA in films with highest amount of $\mathrm{CE}$ ( $8 \mathrm{mg} \mathrm{CE} / \mathrm{cm}^{2}$ of dried film) might be maximum $0.18 \mathrm{mg}$ per $\mathrm{cm}^{2}$. The inhibitory concentration of pure GA in the films on $P$. syringae determined in the current work was $1 \mathrm{mg} / \mathrm{cm}^{2}$. Therefore, it is clear that the CE should be further purified and concentrated and/or enriched with pure GA to be effective on 
<smiles>O=C(O)c1cc(O)c(O)c(O)c1</smiles>

Gallic acid<smiles>COc1cc(C(=O)O)ccc1O</smiles>

Vanillic acid<smiles>O=C(O)/C=C/c1ccccc1</smiles>

Cinnamic acid<smiles>Cc1ccc(C(C)C)c(O)c1</smiles>

Thymol<smiles>Cc1ccc(C(C)C)cc1O</smiles>

Carvacrol<smiles>C=CCc1ccc(O)c(OC)c1</smiles>

Eugenol<smiles>CC(C)=CCC/C(C)=C\C=O</smiles>

Citral

Fig. 3. Open formulas of phenolic acids and essential oils used in this study.

Table 1

Antimicrobial effects of different plant extracts in broth medium.

\begin{tabular}{|c|c|c|c|c|c|c|c|}
\hline \multirow[t]{2}{*}{ Plant Pathogens } & \multirow[t]{2}{*}{ Plant extracts } & \multicolumn{6}{|c|}{ Concentrations of the phenolic compounds $(\mathrm{mg} / \mathrm{ml})$} \\
\hline & & $(0.01-1.28)$ & 2.56 & 5.12 & 10.24 & 20.48 & 40.96 \\
\hline \multicolumn{8}{|l|}{ E. carotovora } \\
\hline & $\mathrm{OE}$ & $\mathrm{NI}^{\mathrm{a}}$ & $\mathrm{NI}$ & NI & $\mathrm{NI}$ & $\mathrm{NI}$ & $47 \%$ \\
\hline & WSE & $\mathrm{NI}$ & $\mathrm{NI}$ & NI & & & \\
\hline & ASE & NI & $\mathrm{NI}$ & $\mathrm{NI}$ & NI & $\mathrm{NI}$ & $48 \%$ \\
\hline & CE & $\mathrm{NI}$ & $\mathrm{NI}$ & $44 \%$ & $100 \%$ & $100 \%$ & $100 \%$ \\
\hline \multicolumn{8}{|l|}{ E. amylovora } \\
\hline & $\mathrm{OE}$ & NI & $\mathrm{NI}$ & $\mathrm{NI}$ & $\mathrm{NI}$ & NI & $91 \%$ \\
\hline & WSE & NI & $\mathrm{NI}$ & NI & & & \\
\hline & ASE & NI & $\mathrm{NI}$ & NI & NI & NI & $48 \%$ \\
\hline & $\mathrm{CE}$ & $\mathrm{NI}$ & $42 \%$ & $82 \%$ & $100 \%$ & $100 \%$ & $100 \%$ \\
\hline \multicolumn{8}{|l|}{ P. syringae } \\
\hline & $\mathrm{OE}$ & $\mathrm{NI}$ & NI & $\mathrm{NI}$ & $\mathrm{NI}$ & $\mathrm{NI}$ & NI \\
\hline & WSE & $\mathrm{NI}$ & NI & NI & & & \\
\hline & ASE & NI & NI & NI & $\mathrm{NI}$ & $\mathrm{NI}$ & $\mathrm{NI}$ \\
\hline & $\mathrm{CE}$ & NI & NI & $\mathrm{NI}$ & $100 \%$ & $100 \%$ & $100 \%$ \\
\hline \multicolumn{8}{|l|}{$X$. vesicatoria } \\
\hline & $\mathrm{OE}$ & NI & NI & $\mathrm{NI}$ & $\mathrm{NI}$ & $73 \%$ & $90 \%$ \\
\hline & WSE & NI & NI & NI & & & \\
\hline & ASE & $\mathrm{NI}$ & $\mathrm{NI}$ & NI & $39 \%$ & $67 \%$ & $68 \%$ \\
\hline & $\mathrm{CE}$ & NI & $57 \%$ & $77 \%$ & $100 \%$ & $100 \%$ & $100 \%$ \\
\hline
\end{tabular}

\footnotetext{
a No inhibition.

b \% value refers the inhibition in bacterial growth.
}

\section{P. syringae.}

\subsection{Morphologies of films}

The morphology of control film clearly showed the porous structure of zein films formed by many homogenously distributed tiny pores and limited number of larger pores (Fig. 5A). The incorporation of different PAs and EOs, and CE into zein films caused different degrees of morphological changes in the films depending on the type of each phenolic component. The addition of GA and CAR caused the most limited changes in morphologies of films (Fig. 5B and C). In contrast, other PAs, EOs and CE caused considerable changes in number and/or size of pores in the films. The addition of CA and VA increased the number of large pores that were also observed in the control films (Fig. 5D and E). In contrast the tiny pores in the films were almost disappeared by the addition of CA and VA. On the other hand, the addition of THY and EUG into films caused dramatic increases in both size and number of pores in the films (Fig. 5F and G). The most dramatic increases in pore sizes were observed in films containing CIT and $\mathrm{CE}$, but these films also contained many tiny pores.

\subsection{Mechanical properties of films}

Some selected stress vs. strain curves are displayed in Fig. 6. The effects of different active compounds on tensile strength, elongation and elastic modulus of zein films are also displayed in Table 2. In majority of the films, the addition of active compounds caused a 


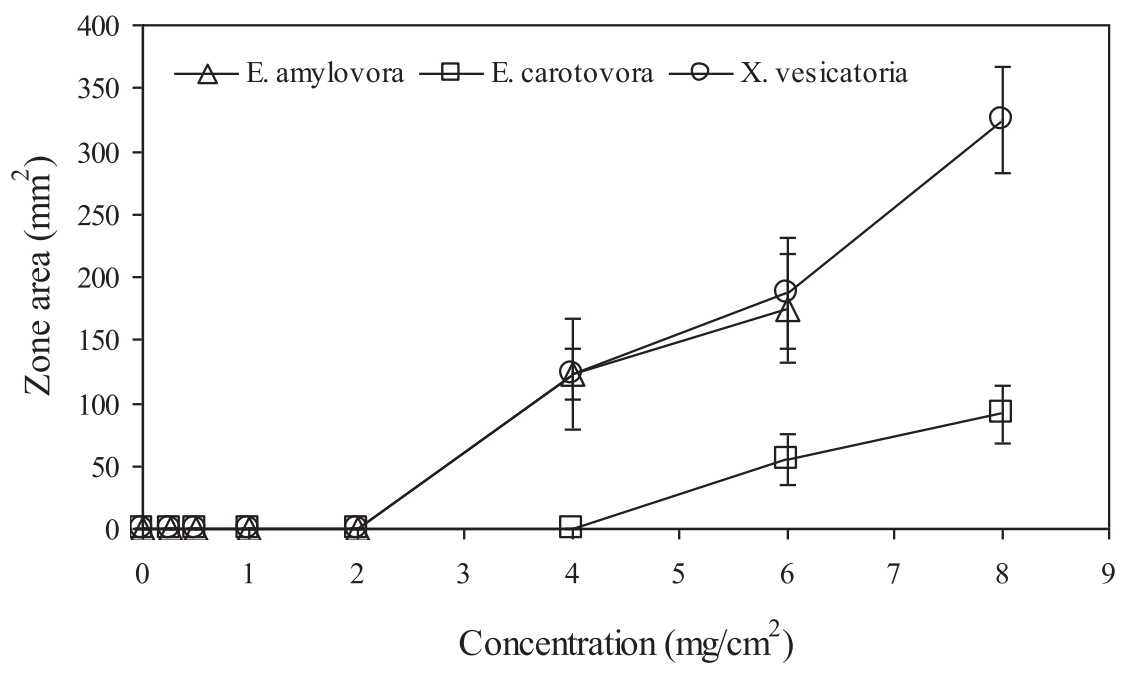

Fig. 4. Antimicrobial activities of clove extract containing zein films on different plant pathogens.

concentration dependent reduction in tensile strength and Young's modulus, and a concentration dependent increase in elongation. However, films containing CIT and CE have different mechanical properties and showed almost no change in their elongation and tensile strengths or showed a limited change in these parameters only at a very high active compound concentration (CE at $8 \mathrm{mg}$ / $\mathrm{cm}^{2}$ ). The VA containing films also differentiated from the others in that they gained a considerable elongation capacity at the concentration of $2 \mathrm{mg} / \mathrm{cm}^{2}$, but lost this capacity when VA concentration was increased to $4 \mathrm{mg} / \mathrm{cm}^{2}$. It might be interesting to report

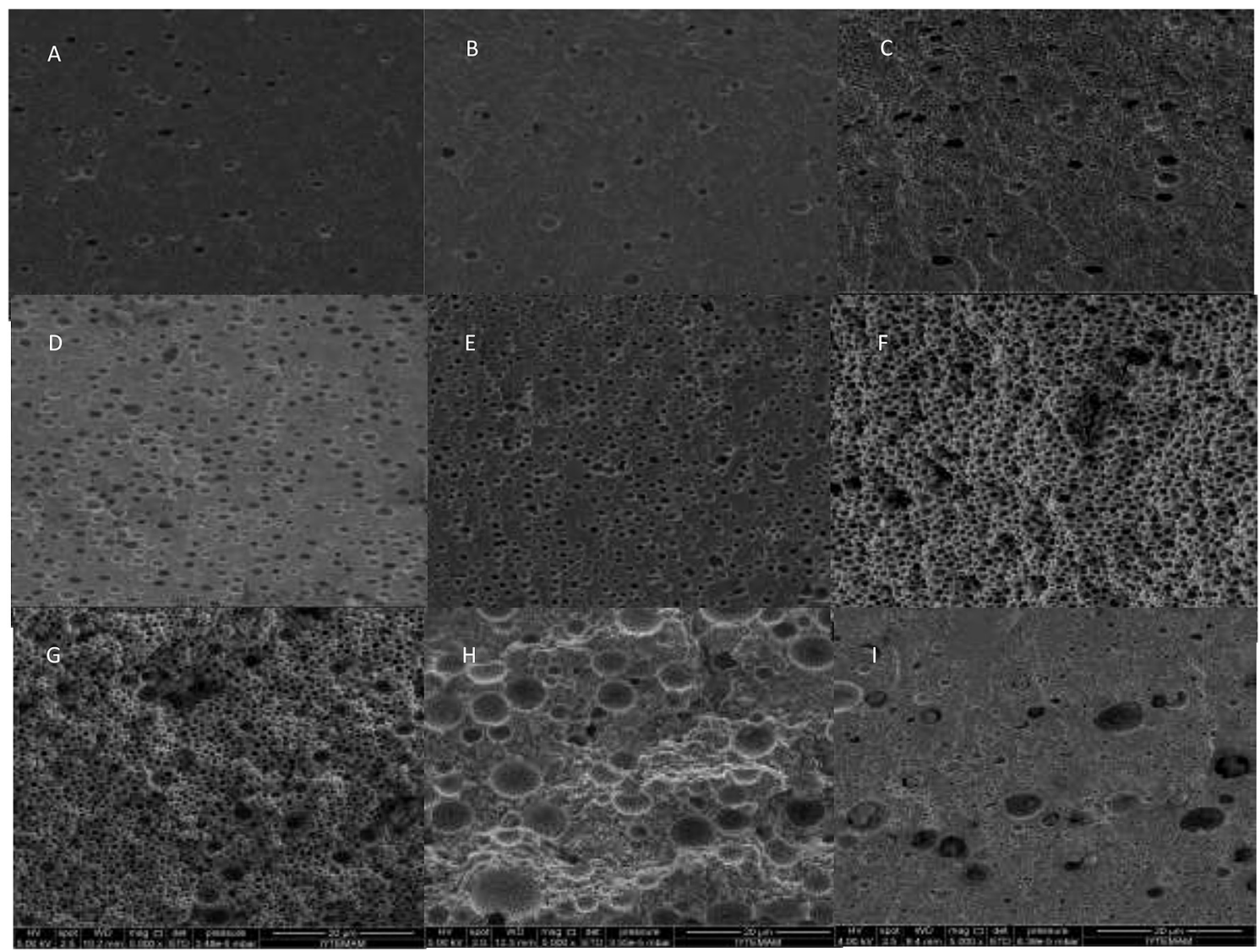

Fig. 5. SEM photographs of different film cross-sections. (A) Control zein film, (B) GA, (C) CAR, (D) CA, (E) VA, (F) THY, (G) EUG, (H) CIT, (I) CE containing films. (Magnifications were $\times 5000$; concentration of PEs and EOs in films was $2 \mathrm{mg} / \mathrm{cm}^{2}$; concentration of CE was $\left.4 \mathrm{mg} / \mathrm{cm}^{2}\right)$. 


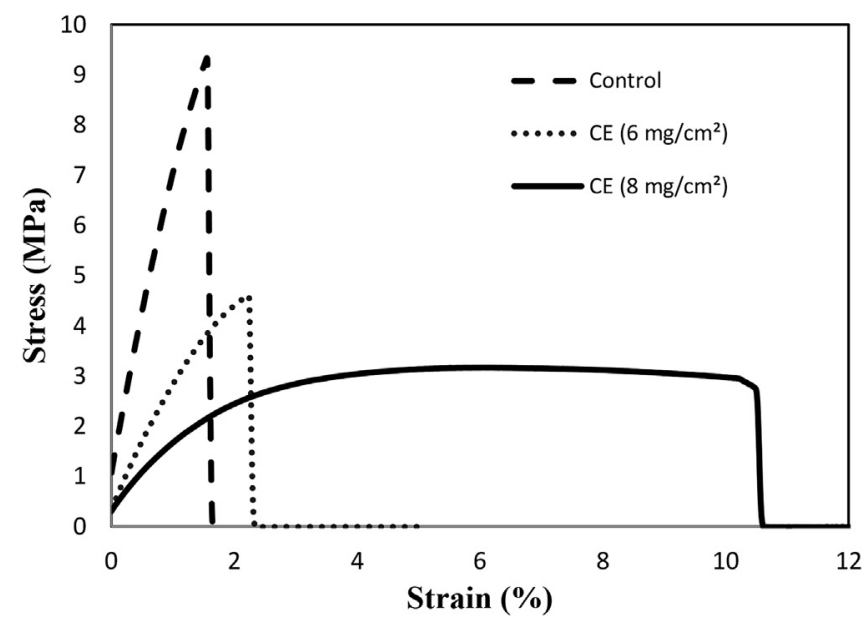

Fig. 6. An example curve showing effects of CA on mechanical properties of zein films.

that addition of CIT and CE caused the most limited changes in mechanical properties such as tensile strength and elongation while causing the formation of largest pores within the zein film matrix. Thus, it is clear that it is very hard to relate mechanical properties and morphologies in zein edible films. However, it seemed that the CIT and CE had a solubility problem within the films during drying and this caused formation of large pores within the film matrix. The plasticizing effect of phenolic compounds in zein film systems was quite expected since this effect of phenolic compounds was well documented not only in zein films (Alkan et al., 2011; Arcan \& Yemenicioğlu, 2011), but also in zein based blend and composite films (Arcan \& Yemenicioğlu, 2013, 2014; Ünalan et al., 2013). Most plasticizers owe their positive effects on film flexibility to their hydroxyl groups which form hydrogen bonds with polymers and increase the free volume of film matrix (Sothornvit \& Krochta, 2005). Thus, the plasticizing effect of phenolic compounds on zein has been attributed to their ability to form H-bonds with their-hydroxyl and -carboxyl groups to peptide amino or carbonyl groups of zein to form a weak flexible network within the film matrix (Alkan et al., 2011; Arcan \& Yemenicioğlu, 2011; Arcan \& Yemenicioğlu, 2013). The zein contains only very limited number of positively charged groups due to its low amounts of basic amino acids ( $\leq 6 \%$ ) (Geraghty, Peifer, Rubenstein, \& Messing, 1981). Thus, binding of negatively charged phenolic compounds on the positively charged groups of zein film matrix is not considered as a major driving force in the plastisization of zein films (Arcan \& Yemenicioğlu, 2011). Recent studies on phenolic release profiles of zein films proved that a portion of incorporated phenolic compounds (change between 12\% and 51\%) is bounded by the zein film matrix, while the remaining phenolic compounds exist in free soluble form (Alkan et al., 2011; Arcan \& Yemenicioğlu, 2011; Arcan \& Yemenicioğlu, 2013, 2014; Del Nobile et al., 2008). The brittleness and lack of flexibility in zein films is mainly due to the hydrophobic interactions that keep the zein molecules together to maintain film integrity (Guo, Liu, An, Li, \& Hu, 2005). Thus, the reduced hydrophobicity of zein film matrix by the increased phenolic hydroxyl groups was also considered as a main factor in increased flexibility of phenolic containing zein films (Alkan et al., 2011). In contrast, the antiplasticizing effect of VA at high concentration $\left(4 \mathrm{mg} / \mathrm{cm}^{2}\right.$ ) could be due to its tendency to show polymerization and increased binding on zein that caused reduced mobility of the film matrix. The report of Emmambux, Stading, and Taylor (2004) who incorporated condensed tannins like tannic acid (TA) into films from sorghum kafirin, a zein like prolamin, and observed an antiplasticizing effect of this polymeric phenolic compound also supports this hypothesis. The change of flexibility in zein films depending on phenolic concentration was also reported by Alkan et al. (2011). Alkan et al. (2011) determined plasticizing and antiplasticizing effects in zein films at GA concentrations of 2.5 and $5 \mathrm{mg} / \mathrm{cm}^{2}$, respectively. In the current study, the antiplasticizing effect of GA was not observed since it was not tested above $4 \mathrm{mg} / \mathrm{cm}^{2}$.

\section{Conclusions}

This work clearly showed the possibility of using edible zein films containing antimicrobial phenolic compounds, essential oils

Table 2

Mechanical properties of different zein films.

\begin{tabular}{|c|c|c|c|c|c|}
\hline Concentration $\left(\mathrm{mg} / \mathrm{cm}^{2}\right)$ & Active compounds & Tensile strength (MPa) & Young's modulus (MPa) & Elongation (\%) & Film thickness $(\mu \mathrm{m})$ \\
\hline- & - & $10.73 \pm 0.59 f^{a}$ & $648.28 \pm 19.78 f$ & $3.69 \pm 0.44 a$ & $115.40 \pm 1.06 a$ \\
\hline 1 & GA & $8.59 \pm 0.42 \mathrm{e}$ & $428.50 \pm 27.10 d$ & $3.52 \pm 0.23 a$ & $115.66 \pm 1.77 a$ \\
\hline 2 & GA & $4.30 \pm 0.45 c$ & $230.27 \pm 7.18 b$ & $31.50 \pm 9.43 a$ & $99.92 \pm 0.95 a$ \\
\hline 4 & GA & $0.87 \pm 0.09 a$ & $28.89 \pm 7.37 a$ & $276.60 \pm 37.16 c$ & $86.40 \pm 1.02 a$ \\
\hline 1 & $\mathrm{CA}$ & $7.47 \pm 1.19 \mathrm{e}$ & $517.37 \pm 29.50 e$ & $4.15 \pm 1.68 a$ & $130.17 \pm 0.78 c$ \\
\hline 2 & $\mathrm{CA}$ & $1.07 \pm 0.16 \mathrm{ab}$ & $168.73 \pm 4.74 b$ & $95.08 \pm 44.80 \mathrm{~b}$ & $137.60 \pm 0.99 c$ \\
\hline 1 & VA & $6.99 \pm 2.38 \mathrm{de}$ & $445.49 \pm 28.11 d$ & $2.75 \pm 1.41 \mathrm{a}$ & $124.98 \pm 0.97 b$ \\
\hline 2 & VA & $1.64 \pm 0.17 b$ & $159.55 \pm 28.75 b$ & $146.26 \pm 90.36 b$ & $142.53 \pm 0.67 d$ \\
\hline 4 & VA & $0.33 \pm 0.16 a$ & $90.05 \pm 6.26 a$ & $12.15 \pm 3.04 a$ & $142.50 \pm 4.33 \mathrm{~d}$ \\
\hline 1 & THY & $5.09 \pm 0.92 \mathrm{~cd}$ & $345.79 \pm 62.59 c$ & $1.55 \pm 0.08 a$ & $128.25 \pm 1.22 b c$ \\
\hline 2 & THY & $2.71 \pm 0.36 b$ & $180.33 \pm 24.80 b$ & $33.61 \pm 17.26 \mathrm{ab}$ & $144.83 \pm 1.00 \mathrm{~d}$ \\
\hline 4 & THY & $1.24 \pm 0.09 \mathrm{ab}$ & $53.25 \pm 7.62 a$ & $366.67 \pm 19.45 d$ & $140.08 \pm 1.57 d$ \\
\hline 1 & CAR & $4.68 \pm 0.95 c d$ & $226.82 \pm 30.92 b$ & $8.79 \pm 1.12 a$ & $129.27 \pm 1.07 c$ \\
\hline 2 & CAR & $2.85 \pm 0.22 b$ & $183.92 \pm 18.63 b$ & $52.74 \pm 15.90 \mathrm{ab}$ & $137.84 \pm 2.60 c$ \\
\hline 4 & CAR & $1.11 \pm 0.53 \mathrm{ab}$ & $37.36 \pm 15.03 a$ & $220.50 \pm 128.19 c$ & $158.67 \pm 1.52 \mathrm{e}$ \\
\hline 1 & EUG & $7.56 \pm 0.81 \mathrm{e}$ & $344.05 \pm 23.07 c$ & $7.83 \pm 3.94 a$ & $134.63 \pm 0.73 c$ \\
\hline 2 & EUG & $2.15 \pm 0.07 b$ & $163.16 \pm 6.50 \mathrm{~b}$ & $238.61 \pm 86.00 c$ & $171.08 \pm 1.44 \mathrm{e}$ \\
\hline 4 & EUG & $1.31 \pm 0.07 \mathrm{ab}$ & $52.57 \pm 2.07 a$ & $394.02 \pm 11.61 d$ & $151.59 \pm 2.41 \mathrm{e}$ \\
\hline 1 & CIT & $4.32 \pm 0.25 \mathrm{~cd}$ & $412.16 \pm 47.39 d$ & $1.21 \pm 0.17 a$ & $157.80 \pm 3.22 \mathrm{e}$ \\
\hline 2 & CIT & $4.52 \pm 0.38 c$ & $383.80 \pm 20.94 \mathrm{~cd}$ & $1.84 \pm 0.22 a$ & $122.07 \pm 1.70 b$ \\
\hline 4 & CIT & $4.51 \pm 0.29 c$ & $370.88 \pm 23.65 c$ & $3.59 \pm 0.69 a$ & $138.71 \pm 3.33 c$ \\
\hline 2 & $\mathrm{CE}$ & $5.82 \pm 0.86 d$ & $553.92 \pm 50.14 \mathrm{e}$ & $0.96 \pm 0.24 a$ & $133.29 \pm 0.77 b$ \\
\hline 4 & $\mathrm{CE}$ & $5.51 \pm 0.84 \mathrm{~cd}$ & $431.36 \pm 52.27 d$ & $1.30 \pm 0.34 \mathrm{ab}$ & $131.25 \pm 1.60 b$ \\
\hline 6 & $\mathrm{CE}$ & $5.92 \pm 0.91 d$ & $336.55 \pm 45.68 c$ & $2.18 \pm 0.32 a$ & $161.18 \pm 1.41 \mathrm{e}$ \\
\hline 8 & $\mathrm{CE}$ & $3.09 \pm 0.26 b$ & $151.27 \pm 10.92 b$ & $9.72 \pm 0.69 a$ & $156.84 \pm 0.88 \mathrm{e}$ \\
\hline
\end{tabular}

a Different letters in each column show significant difference $\mathrm{P}<0.05$. 
and phenolic extracts against bacterial plant pathogens. The application of the developed edible coatings containing natural phenolic antimicrobials in orchards for coating of tree stems could be very beneficial to suppress the bacterial origin plant diseases, maximize product yield and minimize pre and postharvest loss of the products without using toxic chemicals and coatings including Bordeaux mixture. The antimicrobial coatings could also be applied onto surface of contaminated soil or agronomy tools to control and minimize bacterial infections. The edible zein coatings have already been applied successfully on different fruits and vegetables at the post-harvest stage solely to suppress their respiration rates and delay ripening and senescence. Thus, phenolic containing edible zein coatings developed in this work could also provide an additional post-harvest benefit by delaying bacterial spoilage of coated fresh fruits and vegetables. Moreover, the antimicrobial zein coatings could also be applied on seedlings as alternative to toxic and odorous chlorine based disinfectants. The present study is significant in that it is the first study in the literature that uses edible film technology and natural antimicrobial phenolic compounds against bacterial plant pathogens. Further studies are needed to solve the exact mechanisms of inhibition for the bacterial plant pathogens by phenolic compounds and to determine the performance and stability of developed edible coatings on tree stems, fruit and vegetables, and alternative contaminated surfaces in the orchards.

\section{Acknowledgment}

We appreciate the Biotechnology and Bioengineering Research and Application Center in Izmir Institute of Technology for enabling use of their laboratory facilities.

\section{References}

Alboofetileh, M., Rezaei, M., Hosseini, H., \& Abdollahi, M. (2014). Antimicrobial activity of alginate/clay nanocomposite films enriched with essential oils against three common foodborne pathogens. Food Control, 36, 1-7.

Alkan, D., Aydemir, L. Y., Arcan, İ., Yavuzdurmaz, H., Atabay, H.İ., Ceylan, C., et al. (2011). Development of flexible antimicrobial packaging materials against Campylobacter jejuni by incorporation of gallic acid into zein-based films. Journal of Agricultural and Food Chemistry, 59, 11003-11010.

Appendini, P., \& Hotchkiss, J. H. (2002). Review of antimicrobial food packaging. Innovative Food Science \& Emerging Technologies, 3, 113-126.

Arcan, I.., \& Yemenicioğlu, A. (2011). Incorporating phenolic compounds opens a new perspective to use zein films as flexible bioactive packaging materials. Food Research International, 44, 550-556.

Arcan, I., \& Yemenicioglu, A. (2013). Development of flexible zein-wax composite and zein-fatty acid blend films for controlled release of lysozyme. Food Research International, 51, 208-216.

Arcan, I., \& Yemenicioglu, A. (2014). Controlled release properties of Zein-Fatty acid blend films for multiple bioactive compounds. Journal of Agricultural and Food Chemistry, 62, 8238-8246.

ASTM. (2002). Standard test method for tensile properties of thin plastic sheeting D882-02. In ASTM (Ed.), Annual Book of American Standard Testing Methods Philadelphia, PA.

Atarés, L., Bonilla, J., \& Chiralt, A. (2010). Characterization of sodium caseinate-based edible films incorporated with cinnamon or ginger essential oils. Journal of Food Engineering, 100, 678-687.

Bai, J., Baldwin, E. A., \& Hagenmaier, R. H. (2002). Alternatives to Shellac coatings provide, comparable gloss, internal gas modification, and quality for 'Delicious' apple fruit. HortScience, 37(3), 559-563.

Basgedik, B., Aysel, U., \& Nurdan, S. (2014). Antimicrobial, antioxidant, antimutagenic activities, and phenolic compounds of Iris germanica. Industrial Crops and Products, 61, 526-530.

Benavides, S., Villalobos-Carvajal, R., \& Reyes, J. E. (2012). Physical, mechanical and antibacterial properties of alginate film: effect of the crosslinking degree and oregano essential oil concentration. Journal of Food Engineering, 110, 232-239.

Bolan, N., Kunhikrishnan, A., Thangarajan, R., Kumpiene, J., Park, J., Makino, T., et al. (2014). Remediation of heavy metal(loid)s contaminated soils - to mobilize o to immobilize? Journal of Hazardous Materials, 266, 141-166.

Borges, A., Ferreira, C., Saavedra, M. J., \& Simões, M. (2013). Antibacterial activity and mode of action of ferulic and gallic acids against pathogenic bacteria. Microbia Drug Resistance, 19(4), 256-265.

Chakrabarty, S., \& Newton, A. C. (2011). Climate change, plant diseases and food security. Plant Pathology, 60, 2-14.

Chun, S., Vattem, A. A., Lin, Y., \& Shetty, K. (2005). Phenolic antioxidants from clona oregano (Origanum vulgare) with antimicrobial activity against Helicobacter pylori. Process Biochemistry, 40, 809-816.

Cowan, M. M. (1999). Plant products as antimicrobial agents. Clinical Microbiology Reviews, 12, 564-582.

Del Nobile, M. A., Conte, A., Incoronato, A. L., \& Panza, O. (2008). Antimicrobial efficacy and release kinetics of thymol from zein films. Journal of Food Engineering, 89, 57-63.

Dixon, B. (2004). Pushing bordeaux mixture. Infectious diseases (p. 594), 130 Cornwall Road, Ruislip Manor, Middlesex HA4 6AW, UK.

Du, W. X., Olsen, C. W., Avena-Bustillos, R. J., McHugh, T. H., Levin, C. E., \& Friedman, M. (2009). Effects of Allspice, cinnamon, and clove bud essential oils in edible apple films on physical properties and antimicrobial activities. Journal of Food Science, 74(7), 372-378.

Emmambux, M. N., Stading, M., \& Taylor, J. R. N. (2004). Sorghum kafirin film property modification with hydrolysable and condensed tannins. Journal of Cereal Science, 40, 127-135.

Fogliani, B., Raharivelomanana, P., Bianchini, J., Bouraima-Madjebi, S., \& Hnawia, E. (2005). Bioactive ellagitannins from Cunonia macrophylla, an endemic Cunoniaceae from New Caledonia. Phytochemistry, 66, 241-247.

Geraghty, D., Peifer, M. A., Rubenstein, I., \& Messing, J. (1981). The primary structure of a plant storage protein: zein. Nucleic Acid Research, 9(19), 5163-5174.

Gniewosz, M., Synowiec, A., Kraśniewska, K., Przybyl, J. L., Bączek, K., \& Węglarz, Z. (2014). The antimicrobial activity of pullulan film incorporated with meadowsweet flower extracts (Filipendulae ulmariae flos) on postharvest quality of apples. Food Control, 37, 351-361.

Gol, N. B., \& Rao, T. V. R. (2014). Influence of zein and gelatin coatings on the postharvest quality and shelf life extension of mango (Mangifera indica L.). Fruits, 69(2), 101-115.

Gómez-Estaca, J., López de Lacey, A., López-Caballero, M. E., Gómez-Guillén, M. C., \& Montero, P. (2010). Biodegradable gelatin chitosan films incorporated with essential oils as antimicrobial agents for fish preservation. Food Microbiology, 27, 889-896.

Guo, Y. C., Liu, Z. D., An, H. J., Li, M. Q., \& Hu, J. (2005). Nano-structure and properties of maize zein studied by atomic force microscopy. Journal of Cereal Science, $41(3), 277-281$

Han, J. H. (2005). Antimicrobial packaging systems. In H. H. Jung (Ed.), Innovations in food packaging (pp. 80-108). London: Academic Press.

Hao, Y. Y., \& Brackett, R. E. (1994). Pectinase activity of vegetable spoilage bacteria in modified atmosphere. Journal of Food Science, 59, 175-178.

Joerger, R. D. (2007). Antimicrobial films for food applications: a quantitative analysis of their effectiveness. Packaging Technology \& Science, 20(4), 231-273.

Kanmani, P., \& Rhim, J. (2014). Antimicrobial and physical-mechanical properties of agar-based films incorporated with grapefruit seed extract. Carbohydrate Polymers, 102, 708-716.

Kraśniewska, K., Gniewosz, M., Synowiec, A., Przybyl, J. L., Bączek, K., \& Węglarz, Z. (2014). The use of pullulan coating enriched with plant extracts from Satureja hortensis L. to maintain pepper and apple quality and safety. Postharvest Biology and Technology, 90, 63-72.

Lin, D., \& Zhao, Y. (2007). Innovations in the development and application of edible coatings for fresh and minimally processed fruits and vegetables. Comprehensive Reviews in Food Science and Food Safety, 6, 60-75.

Li, K., Yin, S., Ynag, X., Tang, C., \& Wei, Z. (2012). Fabrication and characterization of novel antimicrobial films derived from thymol-loaded zein sodium caseinate (SC) nanoparticles. Journal of Agricultural and Food Chemistry, 60, 11592-11600.

Luzzatto, T., Golan, A., Yishay, M., Bilkis, I., Ben-Ari, J., \& Yedidia, I. (2007). Priming of antimicrobial phenolics during induced resistance response towards Pectobacterium carotovorum in the Ornamental Monocot Calla Lily. Journal of Agricultural and Food Chemistry, 55, 10315-10322.

Mackie, K. A., Müller, T., \& Kandeler, E. (2012). Remediation of copper in vineyards-A mini review. Environmental Pollution, 167, 16-26.

Maddox, C. E., Laur, L. M., \& Tian, L. (2010). Antibacterial activity of phenolic compounds against the phytopathogen xylella fastidiosa. Current Microbiology, 60, 53-58.

Manso, S., Cacho-Nerin, F., Becerril, R., \& Nerìn, C. (2013). Combined analytical and microbiological tools to study the effect on Aspergillus flavus of cinnamon essential oil contained in food packaging. Food Control, 30, 370-378.

Mastromatteo, M., Mastromatteo, M., Conte, A., \& Del Nobile, M. A. (2010). Advances in controlled release devices for food packaging applications. Trends in Food Science \&. Technology, 21(12), 591-598.

Mecitoğlu, Ç., Yemenicioğlu, A., Arslanoğlu, A., Elmacı, Z. S., Korel, F., \& Çetin, A. E. (2006). Incorporation of partially purified hen egg white lysozyme into zein films, for antimicrobial food packaging. Food Research International, 39, 12-21.

Mendes de Souza, P., Fernández, A., López-Carballo, G., Gavara, R., \& HernándezMuñoz, P. (2010). Modified sodium caseinate films as releasing carriers of lysozyme. Food Hydrocolloids, 24(4), 300-306.

Mills, A. A. S., Platt, H. W., \& Hurta, R. A. R. (2006). Sensitivity of Erwinia spp. to salt compounds in vitro and their effect on the development of soft rot in potato tubers in storage. Postharvest Biology and Technology, 41, 208-214.

Mohana, D. C., \& Raveesha, K. A. (2006). Anti-bacterial activity of Caesalpinia coriaria (Jacq.) Willd. against plant pathogenic Xanthomonas pathovars: an ecofriendly approach. Journal of Agricultural Technology, 2, 317-327.

Moure, A., Cruz, J. M., Franco, D., Domìnguez, J. M., Sineiro, J., Domìnguez, H., et al. (2001). Natural antioxidants from residual sources. Food Chemistry, 72, 145-171.

Padgett, T., Han, I. Y., \& Dawson, P. L. (1998). Incorporation of food-grade antimicrobial compounds into biodegradable packaging films. Journal of Food 
Protection, 61, 1330-1335.

Park, H. J. (1999). Development of advanced edible coatings for fruits. Trends in Food Science \& Technology, 10(8), 254-260.

Pimentel, D. (2002). Plant pathogens in biological invasions economic and environmental costs of alien plant, animal, and microbe species (p. 314). CRC Press LLC.

Rojas-Grau, M. A., Avena-Bustillos, R. J., Olsen, C., Friedman, M., Henika, P. R. Martin-Belloso, O., et al. (2007). Effects of plant essential oils and oil compounds on mechanical, barrier and antimicrobial properties of alginate-apple puree edible films. Journal of Food Engineering, 81, 634-641.

Rojas-Graü, M. A., Oms-Oliu, G., Soliva-Fortuny, R., \& Martín-Belloso, O. (2009). The use of packaging techniques to maintain freshness in fresh-cut fruits and vegetables: a review. International Journal of Food Science \& Technology, 44 875-889.

Salgado, P. R., López-Caballero, M. E., Gómez-Guillén, M. C., Mauri, A. N., \& Montero, M. P. (2012). Exploration of the antioxidant and antimicrobial capacity of two sunflower protein concentrate films with naturally present phenolic compounds. Food Hydrocolloids, 29, 374-381.

Scramin, J. A., Britto, D., Forato, L. A., Bernandes-Filho, R., Colnago, L. A., \& Assis, O. B. G. (2011). Characterisation of zein-oleic acid films and applications in fruit coating. International Journal of Food Science \& Technology, 46, 2145-2152.

Shakeri, M., Shahidi, F., Beiraghi-Toosi, S., \& Bahrami, A. (2011). Antimicrobial activity of Zataria multiflora Boiss. essential oil incorporated with whey protein based films on pathogenic and probiotic bacteria. International Journal of Food Science \& Technology, 46, 549-554.

Shan, B., Cai, Y. Z., Sun, M., \& Corke, H. (2005). Antioxidant capacity of 26 spice extracts and characterization of their phenolic constituents. Journal of Agricultural and Food Chemistry, 53(20), 7749-7759.
Shukla, Y. N., Srivastava, A., Kumar, S., \& Kumar, S. (1999). Phytotoxic and antimicrobial constituents of Argyreia speciosa and Oenothera biennis. Journal of Ethnopharmacology, 67, 241-245.

Singleton, V. L., \& Rossi, J. A., Jr. (1965). Colorimetry of total phenolics with phosphomolybdic-phosphotungstic acid reagents. American Journal of Enology and Viticulture, 16(3), 144-158.

Sivakumar, D., \& Bautiata-Banos, S. (2014). A review on the use of essential oils for postharvest decay control and maintenance of fruit quality during storage. Crop Protection, 64, 27-37.

Sothornvit, R., \& Krochta, J. M. (2005). Plasticizers in edible films and coatings. In H. H. Jung (Ed.), Innovations in food packaging (pp. 403-433). London: Academic Press.

Ünalan, İ. U., Arcan, İ., Korel, F., \& Yemenicioğlu, A. (2013). Application of active zein based films with controlled release properties to control Listeria monocytogenes growth and lipid oxidation in fresh Kashar cheese. Innovative Food Science \& Emerging Technologies, 20, 208-214.

Wojdyło, A., Teleszko, M., \& Oszmiański, J. (2014). Antioxidant property and storage stability of quince juice phenolic compounds. Food Chemistry, 152, 261-270.

Wood, E. M., Miles, T. D., \& Wharton, P. S. (2013). The use of natural plant volatile compounds for the control of the potato postharvest diseases, black dot, silver scurf and soft rot. Biological Control, 64, 152-159.

Zapata, P. J., Güillen, F., Martinez-Romero, D., Castillo, S., Valero, D., \& Serrano, M. (2008). Use of alginate or zein as edible coatings to delay postharvest ripening process and to maintain tomato (Solanum lycopersicon Mill) quality. Journal of the Science of Food and Agriculture, 88, 1287-1293.

Zhong, Y., Cavender, G., \& Zhao, Y. (2014). Investigation of different coating application methods on the performance of edible coatings on Mozzarella cheese. Food Science and Technology-LEB, 56, 1-8. 